Government in the role of world peace-maker. The action already taken by the League of Nations, and approved by the Government, in promoting an inquiry into raw materials is obviously in line with the wishes of the signatories. The first essential step is to establish the facts in these matters beyond dispute, and the wisdom and urgency of this step are the more obvious in view of the refusal of certain countries to participate. If, in spite of such refusal, the British Government resolutely persists in a search for some way of reconciling the conflicting claims of different countries, convincing proof will be afforded of Great Britain's desire to promote peace based on a foundation secure because it is just.

\section{Belfast Meeting of the British Medical Association}

The British Medical Association held its one hundred and fifth annual meeting at Belfast last week under the presidency of Prof. R. J. Johnstone, professor of gynæcology in the Queen's University of Belfast. The main theme of his presidential address, entitled "Some Thoughts on Medical Education", was medical education, undergraduate and postgraduate. As a university teacher and member of the General Medical Council, Prof. Johnstone was able to speak with authority from practical experience. He said that the critic of medical education generally assumes that the teachers should, at the end of the five years curriculum, turn out the general practitioner as a finished product, and blames them if they do not do so, although no one expects a finished surgeon, anatomist or pathologist at the end of this period. The specialist must know almost everything about his subject, the general practitioner must know something about almost every medical subject, and the course the latter has to pursue cannot be less difficult than that needed by the former. Although clinical study must have a considerable place in the education of the under. graduate, it is a fallacy to consider that clinical training is the be-all and end-all of medical education. There must be an adequate background of human anatomy, physiology and pathology provided by medical education. Prof. Johnstone also alluded to the existence of dreary lectures and dull teachers, and suggested that courses of instruction in the art of lecturing might be instituted for those appointed to teaching posts.

\section{Nutritional Requirements of Pregnancy}

Aт a joint meeting of the Sections of Obstetrics and Gynæcology and Nutrition, a discussion took place on the nutritional requirements of pregnancy. Sir Robert McCarrison said that the food essentials needed by the prospective mother are, in order of precedence : (1) milk and milk products ; (2) whole or lightly milled cereals, particularly good wholemeal or standard bread, and oatmeal ; (3) green and leafy vegetables; (4) root vegetables, particularly potatoes, carrots and onions ; (5) fruit, including the tomato; (6) pulses ; (7) eggs ; (8) meat, including fish, fowl and glandular organs. To these should be added, in Great Britain, a daily teaspoonful dose of cod liver oil ; a portion of yeast extract is a wise precaution. Dame Louise McIlroy also stressed the value of fresh fruit and vegetables, herrings and wholemeal bread. She suggested that lessons and demonstrations in the preparation and storage of food might well form a part of the work of ante. natal clinics. Other speakers also emphasized the importance of an adequate supply of vitamins during pregnancy. The incidence of puerperal pyrexia seems to be diminished by these means.

\section{Maiden Castle, Dorchester: Excavations in 1937}

Excavatione have now been resumed at Maiden Castle, Dorchester, under the direction of Dr. R. E. Mortimer Wheeler and Colonel C. D. Drew on behalf of the Society of Antiquaries and the Dorset Natural History and Archæological Society (The Times, July 26). Three areas are to be explored in the coming season. At the eastern entrance, the unexpected discoveries made last autumn towards the close of last season's work will be further examined. These earlier fortifications, partly of masonry and dating from the third century B.c., which were found beneath the earthworks screening the entrance, include two outer gateways, which with the inner gateway constitute a complex plan hitherto unknown in prehistoric fortifications. Outside these are areas in which iron was smelted and burials took place. The latter should afford further evidence of the physical characters of the inhabitants, who according to the skeletons found last year were of a small build. Within the fort, investigations will be directed firstly to the Neolithic trenches found last year near the temple, which may have been part of the inner defensive system of the Neolithic partial occupation of c. 2000 B.C.; and secondly to the original western entrance, which was found in December last, but was not then explored. This last is marked by a gap in the rampart, which shows the original western limit of the castle, and should reveal the plan of the earliest gateway known. The first important discovery of the season is that of approach roads diverging in a north-easterly and south-easterly direction, which were superseded and abandoned in the first century B.c. and are thus among the earliest metalled roads known in Britain

\section{Evidence of Early Man at Bethlehem}

To the antiquities from Tell Duweir on view at the Wellcome Research Institution (see Nature, July 17, p. 99) have been added, since the opening of the exhibition, finds from the Bethlehem Bone Beds, which are being excavated by the Wellcome Marston Archæological Research Expedition to the Near East. The work of investigation is being carried out by Miss D. Bate and Miss E. Gardner. The great pit, from the clays of which these finds are derived, appears to be a swallow hole. Rock has been reached on two sides, while on the third side what appears to be only a thin sheet of sloping deposits remains; but until bottom has been reached the exact form cannot be determined. There are indications that the cavity may fork as deposits are followed further. Among the animal remains found in 1937, the most 
striking is the hinder part of the carapace of a gigantic tortoise, together with some detached plates and a bone of the same species. By way of contrast is the fossilized bone of a diminutive species of tortoise. There are also shown part of the tooth of an elephant-the first identification of an elephant in Palestine was from this site--the upper cheek-teeth of a rhinoceros and evidence of a very small form of horse, new to the fauna of Bethlehem. Although there has not yet been opportunity to identify the species with certainty, the indications point to a probably Lower Pleistocene horizon, or even possibly Pliocene. With the animal remains are shown flints selected from a larger number which were found in the bone beds and associated with the fossil fauna. Of these, one is apparently a core, while the others are of characteristic Eolithic or pre-Palæolithic forms. Both the character of the flaking and the forms would seem to place their human origin beyond question. Their association with the animal remains in a definite geological horizon constitutes them the earliest evidence of man's existence yet discovered in Palestine. The exhibition will close on August 7.

\section{"Caves and Caving"}

The British Speleological Association, which met for its second annual conference at Bristol on July 23-26, may now be regarded as fully established. It has acquired Cragdale House, Settle, Yorks, for its headquarters - a 'shilling fund' to raise $£ 500$ has been initiated for its equipment by the women members-and it has issued the first number of a publication under the title "Caves and Caving" (1s., annual subscription $4 s .6 d$.), in which speleological studies will be treated scientifically, but in popular form. The first issue opens with Sir Arthur Keith's presidential address "History from Caves", delivered at Buxton last year, fronted by an excellent portrait of the author; Prof. L. S. Palmer follows with an account of the objects of the Association and its work up to the present, the latest undertaking to which he refers being the systernatic study of the aquatic fauna, to be found in cave streams; Mr. E. Simpson reviews the life-work in speleology of the veteran, M. E. A. Martel, honorary member of the British Speleological Association, and honorary president of the Spéléo Club de France at its founda. tion in 1930. Mr. A. Leslie Armstrong counsels caution in "Cave Exploration as a Science" ; and Dr. Franco Anelli gives an account of the recent descent into La Preta Cavern in the Lessini Mountains of the Veronese, Italy, the deepest known cave in the world, when a depth of 637 metres (approximately 2,090 ft.) was reached. At the recent field meeting of the British Speleological Association at Gaping Ghyll Hole, Ingleborough, Yorks, 356 descents were made and half a mile of new passages were explored. This is Britain's largest cave. The history of its exploration is reviewed by Mr. E. Simpson in a contribution, to be continued. Among other articles is a first instalment of the extremely valuable record of cave finds, arranged under caves, which is being compiled through inquiry by Dr. Wilfrid Jackson.
It will, when complete, show the present location, museum or other, of all animal remains and artefacts of archæological interest found in British caves, so far as can be ascertained.

\section{New Penguin-breeding Record at Edinburgh}

The Scottish National Zoological Park at Edinburgh has long been famous for its penguins-not only for their number and variety and fine condition but also for the manner in which they have bred there. The king penguin bred first in the Park eighteen years ago, and since that time fifteen king penguin chicks have been bred and reared. The ringed penguin and the rockhopper penguin both bred in the Park two years ago. These were the first occasions on which these three species have bred in Britain, and probably the first time they have bred in captivity anywhere. The latest achievement of this kind is the breeding of the gentoo penguin. The gentoo penguin comes next in size to the king penguin. While the king penguin makes no nest but holds its single egg on its feet during incubation, and the rockhopper penguin and ringed penguin make a rough nest of a heap of pebbles, the gentoo penguin prefers something softer, and collects dead grass, twigs and small sticks which it shapes into a symmetrical nest. It was nearly two months after the beginning of the nest building that the first egg was laid, and a second egg was laid five days after the first. Both parents shared in the work of incuba. tion, and took their turns fairly regularly. The first egg hatched after an incubation period of five weeks and four days, but the second was infertile. The chick has a nestling coat of pale grey on the back and white underneath, and it was observed to feed on the day it hatched. It feeds, as do all 'baby' penguins, by taking partially digested fish from the throat of the parent bird.

\section{Acquisitions at the British Museum (Natural History)}

Mr. J. L. Chaworth-Musters has presented to the Department of Zoology 82 birds belonging to 31 species, and a few field mice, which he collected in the High Atlas Mountains, above Marakesh, in the early part of the year. Included among the birds are examples of the rare crimson-winged finch, an alpine accentor, and local forms of the dipper and shore lark. The Entomological Department has received a welcome gift in the letter-book of Dru Drury, a famous collector and describer of insects (1725-1803). He was a goldsmith living in London who had correspondents in Asia, Africa, America, and Australia. This book contains copies, in his own hand, of letters written by him to his friends, his collectors, and his business connexions during the years 1761-1780, and gives a valuable insight into entomological proceedings during that period. Accompanying this volume, and similarly presented by Mr. Charles Dru Drury, are a copy of the auctioneer's catalogue of Dru Drury's collection (1801), and a small collection of letters addressed to him by Carl Linné the younger, by A. R. Lewin (from Australia), and by other well-known contemporary naturalists. 